\title{
A Quaker wedding: the marriage of Bertrand Russell and Alys Pearsall Smith
}

\author{
by Sheila Turcon
}

"EvER YONE IS CONSUMED with curiosity about a Quaker wedding", an excited Alys wrote to Bertie on 25 November I 894, only a few weeks before their marriage at the Friends Meeting House in St. Martin's Lane, Westminster. She went on to say that she was "very sorry to make a sensation" by insisting on the Quaker ceremony. Her concern about the ceremony, however, could not obscure her delight in their approaching marriage. She was extremely happy that she was finally to be married in a religious service to a man of dazzling intellect whom she loved so deeply that her love was a form of worship-a man who had already renounced organized religion but who had agreed to the arrangements at her insistence. The story of Alys and Bertie's relationship, including their troubled and time-tested courtship, their first happy years of married life, their marital problems which led to estrangement, separation and finally divorce, has been recounted elsewhere. ${ }^{1}$ Here the reader will learn of only one

${ }^{1}$ See Barbara Strachey, Remarkable Relations: The Story of the Pearsall Smith Family (London: Victor Gollancz, 1980); Ronald W. Clark, The Life of Bertrand Russell (London: Jonathan Cape and. Weidenfeld \& Nicolson, 1975); Andrew Brink, "Love and Conflict in Bertrand Russell's Letters", Queen's Quarterly, 86 (1979): I-I5.

I would like to thank Edward Milligan and Malcolm Thomas of Friends House Library, Mrs. Barbara Halpern (née Strachey) of Oxford, and Stephen A. Kent of McMaster University for their assistance in researching this article. 
event-Bertrand Russell's first wedding and his last public religious ceremony.

On 30 May I 894 news of their engagement was posted to the Daily Chronicle, the Daily News, the Morning Post, and the Westminster Gazette. The announcement did not contain a wedding date. Bertie's grandmother, the Dowager Countess Russell, who had raised him since the age of three, strongly opposed the marriage. She felt her grandson too young to marry (he was twenty-two at the time) and his choice of bride, an American five years older than himself, highly unsuitable. In an attempt to break the engagement, she insisted on a three-month separation.

Bertie spent most of their time apart as an honorary attaché at the British Embassy in Paris. His grandmother had arranged the appointment through Lord Dufferin, the ambassador at the time. Bertie and Alys therefore had to decide on many of their wedding plans by letter. References to the arrangements for the wedding are scattered throughout their correspondence. In almost all respects, Alys and Bertie's wedding plans were entirely conventional. Alys was intent on impressing her relatives-to-be with her respectability. Her sentiments were expressed most distinctly on I4 September: "I am determined not to do anything that will look like a hole in the corner affair, and give thy charming relations a chance to talk. Thee must fetch me away from my parents' house, in the respectable orthodox way, and after a respectable religious ceremony." Despite her theoretical championing of free love and women's rights, Alys, in her personal life, sought the anonymous cloak of conventionality and conformity. The flamboyant lifestyle of her older sister, Mary, who had left her husband for Bernard Berenson, was anathema. Alys did not want to be judged in polite society by her sister's defiant behaviour.

Alys received her engagement ring in late July. Although the separation period ( 17 August-I 7 November) had not yet begun, it

I would also like to thank Andrew and Helen Brink and Richard A. Rempel of McMaster University for their valuable editorial comments.

Originals of many of the cited letters and Alys's section of "A Locked Diary" are in the possession of Mrs. Halpern; copies are in the Russell Archives. Only some of Russell's separation letters are numbered. would appear that the ring was not personally given but was delivered, perhaps from the jewellery store where the stones had been reset. She noted in their "Locked Diary" (25 July) that the ring, a diamond and four rubies, had come, along with "two pearl brooches, made from an ugly old bracelet of Lady Amberley's". She was "absurdly pleased with the ring." There is no further mention of this ring and no mention at all of wedding rings. Probably she had some choice in the design, and her pleasure with the ring seems only natural. Bertie's reactions are not known, but it can be safely assumed (from his lack of interest in her wedding dress and similar matters) that he was indifferent.

Once the couple was apart, two major topics came to the fore-the honeymoon and the prior mechanics of getting themselves married. The first was easy to resolve; the latter would occupy them during the remainder of the engagement. On 17 September Alys wrote to suggest a Dutch honeymoon: "If it is too cold for walking on the South Coast after our marriage, shall we go to Holland, and have some skating? The Hague is a lovely place, and skating on a Canal would be such fun." Bertie replied two days later in the affirmative: "I have always wished to go skating in Holland-skating is a passion with me, and one seldom gets a chance in England. Besides, it affords a decent means of holding hands in public!" Thus, very briefly, was the honeymoon decided. It was mentioned only once again by Alys, who felt they should stay in the second-best hotel in The Hague.

Arranging the marriage, and especially a marriage of a Quaker to a non-Quaker, was much more time-consuming and complex. Alys was vague on the particular requirements, both civil and religious, that had to be satisfied. In late August, she thought that perhaps the law might require a three-week residency for Bertie in Westminster. ${ }^{2}$ In early September, she was still unclear about the residency requirement but advised him that her mother would find out. ${ }^{3}$ She had the answer by early October. A residency requirement in Westminster was not needed; Bertie could simply get the proper documents from the registrar in his home district of Richmond during the weekend he returned to England at the end

${ }^{2}$ Alys to Russell, 28 Aug. 1894

${ }^{3}$ Alys to Russell, Io Sept. I894. 
of their separation. ${ }^{4}$ She herself had to go to the Westminster registrar as her parents' London home on Grosvenor Road was in that district.

In addition to the government regulations, another set of requirements, those of the Society of Friends, had to be complied with. Only since 1860 had the Society of Friends in Britain allowed marriages between Quakers and non-Quakers. By the I880s half of all Quaker marriages were to non-Quakers. ${ }^{5}$ Thus the marriage of Alys and Bertie was by no means unusual. But Bertie was not only a non-Quaker; he was not even a Christian. In order to clear the way for their marriage, Alys's mother, Hannah Whitall Smith, wrote to Bevan Braithwaite, the "Quaker Pope"6 as Alys referred to him. By the I4th of September Alys could confidently reply: "Mother has heard from Old Pope Bevan B. and he says it will be all right about our marriage. His son will send us legal particulars later on." Braithwaite, as Alys's nickname implies, was a very "weighty" friend. He was also distantly related to Hannah through marriage. Still, it is a measure of Hannah's influence in Quaker evangelical circles that she was on such close terms with him. Conversely, Braithwaite's reply to her, dated 12 September, indicates that he was impressed by "the distinguished family of Russell". His reaction suggests that, even among the Quakers, some were not immune to the prestige of the Russell name. This behaviour is not entirely surprising. Logan Pearsall Smith, Alys's brother, noted in his memoirs that at social gatherings the English Quakers “... seemed unwilling to mix together ... each group keeping aloof from the class which in wealth or social position it considered inferior to itself."7

Bevan's son, William Charles, was appointed clerk of Westminster Meeting on 15 November I894 at the same Monthly Meeting for business which received Alys's membership

${ }^{4}$ Alys to Russell, 3 Oct. I894.

5 Elizabeth Isichei, Victorian Quakers (Oxford: Oxford U.P., I970), p. 164.

"Alys's reference to Braithwaite as the "Quaker Pope" was not unique. Rufus Jones called Braithwaite the "Pope of London Friends" in a letter of I7 October I886. See Elizabeth Gray Vining, Friend of Life: The Biography of Rufus M. Fones (New York: J. B. Lippincott Co., I958), p. 5o.

${ }^{7}$ Logan Pearsall Smith, Unforgotten Years (Boston: Little, Brown, 1939), p. 133. certificate from America. ${ }^{8}$ She reported to Bertie on 12 November that the document had arrived just in time for the Monthly Meeting to receive it. With the Braithwaites in charge, Alys was naturally confident that "... the legal formalities can all be gone thro" with in less than a month after thee comes home, Nov. 17th. We could begin proceedings earlier by sending thee the papers to fill out, but I would rather wait until the time is up" (3 Oct.). In addition to her desire to wait for the three-month separation period to expire, the necessary marriage papers probably could not have been processed before Alys's certificate was transferred. The following marriage documents had to be completed:

I. A declaration of intention of marriage, signed by each party, each signature being witnessed.

2. A certificate of consent of parents or guardians (which could be dispensed with).

3. A ... declaration [of intention] from a non-member. [See Appendix I for content.]

4. A ... certificate from the registering officer [of the Monthly Meeting] ... acceding to the application by a non-member. (This [form] had to ... be produced to the [civil] superintendent registrar.)

5. A certificate that publication of intention of marriage has been given at the close of meeting for worship....9

A couple would be free to marry after seven full days following the satisfaction of the fifth requirement. Their freedom to marry, or "liberation", then was certified by the clerk and an overseer of the Monthly Meeting.

It is quite clear that the Monthly Meeting of 15 November could not appoint a meeting date for the Pearsall Smith-Russell wedding. With Bertie still in France, all the paperwork still lay ahead. Alys worked with dispatch when he finally returned. Marriage documents I through 3 (with 2 probably being dispensed with) were completed in less than one week. She visited the Westmins-

${ }^{8}$ Removal Certificate Register, I886-I9I5, Friends House Library.

${ }^{9}$ Edward Milligan to author, 15 Aug. 1983. (This letter is now in the Russell Archives, Rec. Acq. 821.) Marriage documents from this period unfortunately are not extant. 
ter registrar on 2I November and for the payment of a fee made the necessary arrangements to obtain a licence to marry (rather than a certificate). A licence meant that notice did not have to be given to the registrar of the district in which the other party resided. ${ }^{10}$ Since Bertie had already been to see the Richmond registrar, it is somewhat puzzling why a licence was obtained. Possible explanations include either that Alys was not entirely clear on the regulations or that some problem may have arisen in Richmond. The licence was issued on 22 November by the Westminster registrar, whom Alys found "witty" and "amusing"; she even invited the registrar to the wedding, although Quaker practice did not require him to attend, as normally would be the case for weddings in his district. ${ }^{11}$ On 25 November public notice of the upcoming wedding was given at the Westminster weekly meeting for worship. ${ }^{12}$

The couple had no time left, however, for the next regular Monthly Meeting to appoint a meeting for the solemnization of the marriage. With the 1888 changes to the regulations, this was no longer a strict legal requirement. ${ }^{13}$ Yet it was still the custom for the Monthly Meeting to do so. In what was surely an unusual occurrence, the wedding took place on the I 3 th of December, hours ahead of the Monthly Meeting. The Westminster Monthly Meeting Minute Book records that their marriage was "duly liberated by the clerk and an overseer of our M.M. and was duly solemnized ... and legally registered." 14 It must be remembered, too, that if the date of the wedding had not been changed in late November to comply with Countess Russell's wishes (as discussed later), the couple would have married one day after the Monthly Meeting.

The mechanics of arranging for the marriage were one aspect of the impending event. It is also appropriate to consider how Bertie

${ }^{10}$ Alys's section of "A Locked Diary", 21 Nov. I894 entry; Book of Christian Discipline of the Religious Society of Friends in Great Britain, 5th ed. (London: Harris, I883), p. 283.

${ }^{11}$ Alys to Russell, 21 Nov. I894.

${ }^{12}$ Alys's section of "A Locked Diary", 25 Nov. I 894 entry.

${ }^{13}$ Edward Milligan to author, 15 Aug. 1983.

${ }^{14}$ Westminster Meeting House Minute Book, I3 Dec. I894, Friends House Library. and Alys felt about their approaching Quaker wedding. Bertie's attitude was basically one of forebearance before the inevitable. He seems to have suffered no qualms about participating in a religious ceremony as a non-believer. This judgment is reinforced by a letter he received a decade later from John Pollock, son of Sir Frederick Pollock, who was obviously in deep distress concerning his impending nuptials. Pollock asked: "... how much, if at all, is the act of being married in a church taken as an implied profession of belief in or acceptance of the doctrines of the church or adherence to it?"15 Unfortunately Russell's reply is not extant. However, Pollock's follow-up letter makes it appear that Russell had advised him to consider proceeding with the religious ceremony. This action would be justified by the desire to spare Pollock's people from fears that hell lay ahead of him if he had a civil marriage.

As part of his introduction to Quakerism, Bertie attended a meeting for worship with the Pearsall Smiths in late November. His conduct must have been exemplary. His future mother-in-law related the incident in her circular letter $\# 87$ to her family:

Bertrand had never been to a Friends' meeting in his life ... [before] Alys took him.... Bevan Braithwaite preached a nice old fashioned Quaker sermon, and Bertrand was very much pleased. At the close of the meeting the dear old man came down the aisle and gave Bertrand a very patriarchial blessing which made him feel quite at home. $\quad(26$ Nov. 1894)

Bertie was obviously willing to conform outwardly with what was expected of him in the brief period preceding the wedding. As Appendix I makes clear, the Quaker regulations were accommodating to non-members, allowing for a minimum of strain on both sides. The declaration of intent to marry was simply that; there was no need for Bertie to profess formally beliefs he no

${ }^{15}$ Pollock to Russell, 25 Feb. I904. Although Russell's reply to Pollock was kind, privately Russell considered Pollock a religious hypocrite. Apparently later, he crossed out Pollock's name and pencilled in "Tartuffe up to date" on both letters. This judgment seems unduly harsh considering Pollock's situation paralleled his own in the previous decade. 
longer held.

Any doubts he might have had about participating in a religious ceremony had articulated themselves in the early days of their separation when he suggested that they have a civil marriage. He assured Alys that marriage by the Consul of the British Embassy in Paris would be "eminently respectable" (12 Sept., \#35). Alys quickly vetoed the idea as not being in accordance with her image of Victorian respectability. Bertie did not press the matter. His suggestion was made partly out of his desire to have her join him in Paris before their separation ended. The subject, however, must have worried Alys more than she was willing to discuss in September. She returned to the subject on I November, when she assured Bertie that a Mrs. Philpot had been "so sympathetic, especially about our being married at the Meeting-House instead of a Registry Office."

She worried that her decision to have a religious wedding was unfair to Bertie. But there was no alternative in terms of family wishes and the dictates of society. As she put it succinctly in mid-September: "I hate to make thee go through a religious ceremony, but I am sure thee must see hotw the other would give thy $\mathrm{Gm}$. [Grandmother] unnecessary pain and make thy relations talk" ( 14 Sept.). At the beginning of November, she again expressed regret about forcing him to participate. This time she qualified her remarks in a more positive manner: "Personally, I love that marriage service, and have always longed to be married that way, but of course I know thee can't have any of that feeling, and it is hard on thee" (I Nov.). In late November she was still concerned but felt confident that she had made the right choice and had selected the right service: "I am very sorry to make a sensation in this way, but thy Gm. never would have consented to a Registry Office, and even Canon W[ilberforce] admitted that the C[hurch] of Eng[land] service is too disgusting for words" (25 Nov.). Bertie tried to reassure Alys at the beginning of November that he was quite willing to bend to her wishes, but his own petulant feelings surfaced as well. He was too immature at twenty-two to capitulate with grace despite Alys's concerns. His shyness, although denied by him at the time, may also have been a motivating factor when he wrote: "Don't imagine I really seriously mind a religious ceremony-any ceremony is disgusting, and the mere fact of having to advertise the most intimate thing imaginable is loathsome to me ..." (23 Nov., \# I08). He did try to make amends for his unpleasant attitude later in the month by apologizing for writing "so much about disliking the fuss of the wedding" ( 28 Nov.). He blamed his prickliness on his fluctuating moods. Only two days earlier he had poked fun at the situation when he wrote that he had composed the opening line of an extempore prayer"From all Quaker Weddings Good Lord deliver us" (26 Nov.).

Although Alys's attitude toward the wedding was generally favourable, her religious beliefs were in flux during the engagement. In Russell's Autobiography he mentions that they "had frequently had arguments about Christianity, but I did not succeed in changing her opinions until a few months after we were married." 16 This statement simplifies matters by implying that Alys's change of heart regarding religion took place only after the wedding. Yet as early as the I8th of September she was confessing to him: "I don't know whether I believe in a God now or not, but I do believe in thee, and I simply worship thee ... our love is a sort of religion, and is absolutely pure and holy and good." At Friday's Hill, in October, she was reluctant to attend Sunday worship with her mother. A limerick appears in one of her letters ( 7 Oct.) which neatly sums up her balancing of her mother, the respectability of a proper wedding, and her fondness for the plain yet dignified Quaker ceremony on the one side, and Bertie's unassailable logic on the falsity of religion on the other:

There was a young wife in Belgravia Who had ceased to believe in her Saviour But nobody knew

She belonged to that crew

So circumspect was her behaviour.

Only a week later her views on the subject appear to have developed as far as she would allow them until she was safely married:

I have a great deal to say on religion, or rather there is a great deal in my

${ }^{16}$ The Autobiography of Bertrand Russell, Vol. I: 1872-1914 (London: George Allen \& Unwin, 1967), p. I24. 
mind; but it's very misty and I cannot express it somehow.... My agreeing with thy opinions is only a matter of time, tho' I hope I shall always be more tolerant of Christianity than thee has been so far. But there isn't any hurry, is there, for me to formulate what I think? I would so much rather do it when I am with thee ... I am only too thankful that we shall be at one about this last subject. But I don't want to formulate or express too much while I'm living with Mother. (I3 Oct.)

Alys and Bertie's concerns with religion centered around their personal situation. They appear to have had little or no knowledge of the revolution in Quaker theology and its repercussions for social policy in the I89os. A renewed emphasis on the "Inner Light" as the distinctive Quaker belief was articulated with clarity and freshness at the Manchester Conference of $1895 .{ }^{17}$ This shift in Quaker policy towards new forms of social action was in opposition to the old-fashioned philanthropy of the evangelical wing of Quakerism to which the Pearsall Smiths were loosely attached.18 Putting further distance between Alys and Bertie and the new developments was the fact that the Smith family links to Quakerism were often tenuous, as Remarkable Relations makes clear. Thus Alys and Bertie had no external pressure exerted upon them to become involved in the new movement. And their personal inclinations lay elsewhere. It was only long after his "Quaker" marriage had ended in all but name that Russell was again to come into close contact with Quakerism. His interaction

${ }^{17}$ See Isichei, Victorian Quakers, pp. 32-43; also her "From Sect to Denomination among English Quakers", in Patterns of Sectarianism, ed. Byran R. Wilson (Toronto: Heinemann Education Bks., 1967), particularly p. I75; Richenda C. Scott, "Authority or Experience: John Wilhem Rowntree and the Dilemma of 19th Century British Quakerism", Fournal of the Friends Historical Society, 49 (1960): 86-7; Manchester Conference of the Society of Friends (London: Headley Brothers, 1895 ).

${ }^{18}$ Alys's philanthropic activities are outlined in Remarkable Relations. She was in charge of the "Y" or Youth Branches of the British Women's Temperance Association and was also involved in club work with young female factory workers. Bertie was immersed in his academic career. Yet he, too, had "philanthropic impulses" which were often repressed because of his work. See "Journal [1902-05]" in Contemplation and Action, 1902-1914, Vol. 12 of The Collected Papers of Bertrand Russell (London and Boston: Allen \& Unwin, forthcoming), p. 27. with the Society of Friends on behalf of the peace movement during the Great War marked the beginning of a far more serious phase in his relationship with Quakerism. ${ }^{19}$ At the time of his marriage, he and Alys planned an academic life together, beginning with study in Berlin.

Before this new life could begin, the wedding arrangements had to be completed by Alys. Like most brides, she had a myriad of details to attend to-drawing up the guest list, sending invitations, selecting a wedding dress and trousseau, deciding whether to have a reception and bridesmaids, picking an exact date, and receiving and acknowledging wedding gifts. And all this had to be done with an eye to placating her contentious future in-laws-not an easy task, given their opposition to the union.

The matter of the reception was most promptly dealt withthere was to be none. On I2 September Alys wrote to Bertie after attending someone else's reception: "Thank the Lord, thee and I shall not feel it is our duty to subject our friends to any such a trial after we are married." And on 8 October she again remarked that it was lovely that there would be no reception. On the surface, everyone appeared to be in agreement. Yet there is some reason to believe that Alys would have considered a reception if her mother had not adamantly opposed it. Alys did decide to hold "a tea-party for the Club Girls a day or two before the wedding"20 to avoid disappointment for them. She also considered reversing the plans for a reception but told Bertie it was impossible because her mother insisted that the wedding be kept simple and refused to entertain the idea of having any guests to the house (Io Oct.). There were other reasons for not having a reception. Alys remarked to Bertie in early October that "We can ask all thy relatives to the Meeting house, but they probably won't come as it will be in the holidays" ( 8 Oct.). Not having a reception assured Alys that she would not be embarrassed socially if the entire Russell family did not attend the wedding. Conversely, if the family did come, Alys would not be forced to socialize with people who had tried so hard to ostracize her. When Bertie and Alys first

\footnotetext{
${ }^{19}$ See The Autobiography of Bertrand Russell, Vol. 2: 1914-I944 (London: George
}

\footnotetext{
Allen and Unwin, I968), pp. 38-40.

${ }^{20}$ Alys to Russell, 8 Oct. I894.
} 
formulated their wedding plans, they saw their quick departure after the ceremony as an escape from the cruelty of his relatives.

- Alys's wedding arrangements were in marked contrast to her sister's Roman Catholic wedding in Oxford to Frank Costelloe the preceding decade. That wedding had been both large and lavish, with Mary's wedding dress having been made in Paris ${ }^{21}$ and the ceremony followed by an elaborate wedding breakfast at Balliol College Hall. ${ }^{22}$ Hannah had been able to endure what she felt to be a "refined form of torture" 23 for Mary, but she was unwilling to do so for her younger daughter. Even though Alys's wedding was considered simple, the guests numbered over $200 .{ }^{24}$ It can only be assumed that etiquette would have required a reception. Hannah's comment in her circular letter to the family that they were using Countess Russell's health as an excuse not to hold a reception supports this assumption. Yet despite varying motivations and feelings about the reception, the initial decision not to have one remained unchanged.

Unfortunately, the opposite situation arose with regard to bridesmaids: Alys's decision to have her two young nieces, Ray and Karin Costelloe, as bridesmaids had to be reversed. On 5 October she told Bertie that the girls were "enchanted" by the idea. Then their father created problems. He refused permission for the children to be present at the wedding with their mother, from whom he was estranged. ${ }^{25}$ Alys attempted to understand his position. ${ }^{26}$ The situation was finally resolved when their mother agreed not to attend the ceremony. Probably to help camouflage her absence, the girls did not play a prominent role as bridesmaids. According to Hannah, they "... looked lovely in their blue velvet Liberty dresses and white felt hats, and they sat through the meeting like angels of goodness." 27 One can only hope they were not too disappointed.

${ }^{21}$ Strachey, Remarkable Relations, p. 83.

${ }^{22}$ Logan Pearsall Smith, Unforgotten Years, p. 132.

${ }^{23}$ Hannah Whitall Smith, Circular Letter \#87, 26. Nov. 1894.

${ }^{24}$ Philadelphia Public Ledger, undated clipping in Russell Archives.

${ }^{25}$ Alys to Russell, 22 Oct. I 894.

${ }^{26}$ Alys to Russell, 27 Oct. 1894 .

${ }^{27}$ Hannah Whitall Smith to Mary Costelloe, I3 Dec. 1894.
Bertie also experienced uncertainties on details of the wedding, particularly on the question of a best man. In late November he asked Alys: "I believe I don't require a best man-if I did, I should ask Crompton, and Marsh if C. failed. Do I need one? I should rather like one of them if there is room for such a person" ( 28 Nov.). Curiously enough, on the same day Bertie's brother, Frank, wrote to Alys: "I will support Bertie with pleasure on the great day: though I confess I am rather afraid of the whole thing, which has to my Tory mind something irregular and Dissenting about it." It appears that Alys played some role in selecting the Earl Russell as the best man. The two official witnesses for the wedding were Frank and Alys's father.

The wedding date was another decision which had to be made. Controversy arose over the original date of 14 December. The I 4 th of the month had sentimental value for Alys and Bertie. He fondly recalled that his first proposal had been made on 14 September, fifteen months earlier (24 Oct., \#89). Alys, too hastily in fact, believed the decision would be theirs alone. "Fortunately," she wrote, "it is not the conventional thing to consult the man's family about the date of the marriage" (12 Oct.). The final element in their choice of the I $4^{\text {th }}$ was Alys's decision, with Sidney Webb's encouragement, to run for office in the Westminster Vestry. Sidney and Beatrice Webb, leading members of the Fabian Society and founders of the London School of Economics, were friends and neighbours of the Pearsall Smiths. In a discussion Alys had with them on 23 October, they had decided that since she was still an American citizen, marriage to Bertie would be a necessary qualification to stand for election. The I 5 th of December was the date scheduled for voting. When Countess Russell decided that the I4th was unsuitable because it marked the anniversary of the death of Prince Albert, Alys and Bertie had no alternative but to move the date forward to the 13 th. Countess Russell, who played the role of villainess so convincingly during the entire courtship and engagement, was capable of some generosity in defeat-she arranged with Lord Dufferin to let Bertie leave Paris on I December, ten days before his three-month term at the Embassy was officially over. ${ }^{28}$ There was still time for one more minor skirmish.

${ }^{28}$ Alys to Russell, Ir Nov. 1894 
Both Countess Russell and her daughter, Lady Agatha, objected to the use of Bertie's title of Honourable in the invitations. ${ }^{29}$ The Pearsall Smiths, uncertain of the subtle nuances of aristocratic etiquette, decided to include the title, after being assured by Frank Russell and Maude Stanley, his aunt, of its correctness.

With the date now firmly fixed, the wedding invitations could be ordered and mailed. Bertie left Alys to draw up the invitation list, in consultation with the Stanleys and Russells. His comments on who should come were brief and unhelpful. On 25 November he wrote: "Both wives [Ward's and Sidgwick's] are very remarkable women, but I don't know if they're to be asked or not-I don't understand such things" (\#6). Oddly enough, considering his dislike of the Embassy people, he suggested to Alys that some of them should be invited (29 Nov.). Perhaps his aristocratic sense of propriety was at work. It has been possible to construct a partial list of those who either were invited or attended the wedding (see Appendix II). There was a diversified mixture of people including some of Bertie's aristocratic relatives, his Cambridge friends, friends of the Pearsall Smiths, and Alys's factory girls.

Wedding gifts had begun to arrive as'soon as the engagement was announced, and by November the trickle became a flood. Alys kept a list of all gifts received in the back of their "Locked Diary". There are 216 entries in the list, although some of the names are repeated (see Appendix III). Bertie only made one comment on the gifts, despite Alys's regular chronicling of their arrival. Before lunching with the Dufferins on 3I October he wrote, "There is one advantage in my being here: they'll have to give us wedding presents!" (\# IOO). Alys did not hesitate to let people know what she would like. She wrote to Edith Thomas, an American cousin, saying books were welcome and suggesting complete sets of Henry James, Howells, and Hawthorne among others, qualifying her remarks to Bertie with "American patriotism will prefer to give American books" (8 Oct.). Gifts of money were set aside to "feather" their "little nest" ( 26 Oct.). Not all gifts were likedone calendar case was described as hideous (27 Oct.). A list of "hoped-for" gifts was circulated because Alys commented to Bertie that it would be nice if "... we receive all the useful things on

${ }^{29}$ Alys's section of "A Locked Diary", 26 Nov. I894 entry. that list we made out, bedroom chairs, etc." ( 5 Nov.). She even wanted to know what her own present from Bertie would be (ibid.). And she began to see her colleagues in the British Women's Temperance Association (BWTA) as mere sources of gifts: "I'm growing terribly mercenary-I only regard these women with an eye as to which ones are likely to give me weddingpresents, I am so afraid they'll give me perfectly hideous things" (I3 Nov.). She hoped that Mrs. George Cadbury, wife of the famous Birmingham cocoa magnate, might send a three-foot box of chocolates. Alys was certainly not circumspect in her delight at receiving so many gifts. But she had no intention of doing all the thank-you notes herself. Some of the gifts were addressed to Bertie, and she expected him to acknowledge them. (They are marked by a "B." on the gift list.) One of the most unusual gifts was a poem by the two poetesses who called themselves Michael Field. Entitled "Marriage Vows", this poem is of such poor quality it does not bear repeating. One can only wonder what Alys and Bertie's reaction to it was.

The night before the wedding found both Alys and Bertie campaigning for her election-a devotion to public duty which characterized much of their marriage. The wedding itself was reported as a huge success. ${ }^{30}$ Alys wore a fawn-coloured velvet dress, trimmed with white silk embroidered with gold, which was considered suitable to wear as a travelling dress after the ceremony. It was designed by Lady Henry Somerset, President of the BWTA. Countess Russell had "made an awful outcry" because the dress was not white. ${ }^{31}$ White dresses were regarded more as symbols of affluence than badges of virginity-but her exact reason for objecting is not known. Alys's hat was white felt with ostrich feathers. She carried no flowers.

${ }^{30}$ An account of the wedding was published in Woman's Signal, 27 Dec. 1894. It was also fully described in Hannah Whitall Smith's Circular Letter \# 88, 26 Dec. I 894. Clark's account of the wedding is mistaken in stating that "none of the Russells was present" (p. 58). Alys's wedding attire in the illustrative sketch is not accurate. The seating arrangements in the sketch are slightly altered from the description provided by Hannah Whitall Smith.

${ }^{31}$ Alys to Russell, 26 Nov. 1894. Some background information on wedding customs is provided in Elizabeth Laverack, With This Ring: 1oo Years of Marriage (London: Elmtree Books, 1979). 




Entering the large, square room of the Meeting House ${ }^{32}$ on her father's arm, followed by her mother and her brother, she met Bertie in front of the gallery, a set of raised facing benches. They then sat down on these benches with Alys's parents beside her and Frank Russell, Lord Carlisle and Lady Cecilia Roberts beside him. Although Bertie's grandmother, Aunt Agatha, and Uncle Rollo were not there, the wedding was not totally boycotted by the Russell family. After William Braithwaite explained to the guests how a Friends meeting is conducted, Alys and Bertie rose to say their vows. The couple wed each other, as ministers are regarded as unnecessary in the Quaker faith. The vows are straightforward and democratic in tone. Identical in meaning for both parties, for Bertie they would have been:

Friends, I take this my friend Alys to be my wife promising through Divine assistance to be unto her a loving and faithful husband until it shall please the Lord by death to separate us. ${ }^{33}$

After the vows were completed and the certificate signed and witnessed, it was read aloud by the registering officer. Hannah wrote to Mary that "both Bertie and Alys said the ceremony beautifully, without the least apparent nervousness" (1 3 Dec.). In their correspondence before the wedding, neither had thought they would be nervous. But Russell's daughter, Katharine Tait, remembers that in later years when he talked about his Quaker

${ }^{32}$ For a brief history of Westminster Meeting House, see Doris and Douglas Lee, Glimpses of Westminster Meeting, 1655-1956 (London: Published by Westminster Friends Meeting, 1983). The Meeting House was bombed during the Second World War and the room in which the wedding took place was destroyed. It was later rebuilt on the same location.

${ }^{33}$ Quaker women did not have to promise to obey their husbands as did Anglicans. Indeed, it can be argued that the Society of Friends offered women marginally greater opportunities for participation and advancement than was generally available in late Victorian middle-class society. Alys and Bertie did discuss in their letters their hopes to fashion a marriage based on mutual respect and the pursuit of their own interests. But even during I 893 and I894 signs were present that the marriage would develop into a relationship which was in many ways conventionally Victorian. From the beginning Bertie's career came first, and Alys, besotted by love, was a willing accomplice in the devaluation of her own goals and achievements. 
wedding he said that he had found the whole experience terrifying. ${ }^{34}$ The vows were followed by periods of silence interspersed with brief vocal ministry. Then the ceremony was over. Alys and Bertie, after bidding their guests goodbye, left directly for the train station while the guests, as is the Quaker custom, stayed behind to sign the marriage certificate. ${ }^{35}$

Their honeymoon in The Hague at the Hotel Twee Stenden, where they had a charming and comfortable two-room suite, appeared to pass idyllically. Alys wrote to her mother that they had spent their first day together taking "a walk on the sea-shore at Schiveningen in a splendid storm of wind.... We ... do nothing but laugh all the time" (I6 Dec.). The trials and delights of the wedding ceremony over, Bertie and Alys joyfully began their marriage, which in its first few years was to bring them much happiness.

\section{The Bertrand Russell Editorial Project McMaster University}

${ }^{34}$ Katharine Tait in conversation with the author.

35 There were two marriage certificates. Only one is known to be extant-the standard one, in a record book at Friends House Library. The whereabouts of the Quaker certificate, which would have contained the marriage vows and all the signatures of guests, is unknown.

\section{APPENDIX I}

\section{Declaration of a non-member}

I hereby declare that I am desirous of being married according to the usages of the Society of Friends, and, if permission so to do be granted, I undertake to comply in all respects with the regulations of the Society in relation to marriage.

The declaration required the signatures of two Friends to the following:

We, the undersigned, witnesses to the foregoing signature, are of opinion that permission to be married according to our usages may suitably be granted to by the monthly meeting.
APPENDIX II

Invited to the Wedding (attendance not confirmed):

Duke of Bedford [head of the Russell family]

Biddulph boy at Cambridge [a Stanley family connection]

Viscount Belhaven (Capt. Alex Hamilton) [a Stanley relative]

T. J. Cobden-Sanderson [friend of Bertie's parents, the Amberleys, and Bertie's "godfather"]

Cromptons [friends of the Amberleys]

Frasers [friends of the Amberleys]

Stanley Makower [Bertie's Cambridge friend]

Edward Marsh [another Cambridge friend]

Oswald Sickert [another Cambridge friend]

Henry Sidgwick [and wife?] [Cambridge tutor]

A. G. Tansley [Bertie's Cambridge friend]

James Ward [and wife?] [Cambridge tutor]

Wedding Guests (attendance confirmed by reports of the wedding):

Countess of Airlie [a Stanley relative]

Lord Carlisle [a Russell relative]

Frank, Ray, and Karin Costelloe [Alys's brother-in-law and daughters]

Bevan and William Braithwaite [prominent Quakers; William was a scholar and historian]

Mr. Clifford [an artist]

Club girls [Alys's factory girls]

Miss Elliot [possibly related to Countess Russell]

Rev. Alfred Gurney

Lady Albinia Hobart-Hampden

Rendel Harris [first Director of Studies of Woodbrooke, a Quaker institution of higher learning at Birmingham]

Frederick Harrison [author and positivist]

Sir John and Lady Lubbock [Stanley relatives]

Lady Isabel Margesson

Will Rothenstein [artist]

West London Mission group of sisters

Lady Cecilia Roberts [a Russell relative]

Frank Russell [Bertie's brother]

Logan Pearsall Smith [Alys's brother]

Mr. and Mrs. Horace Smith [Alys's aunt and uncle]

Mr. and Mrs. Robert Pearsall Smith [Alys's parents]

Hon. Lyulph Stanley [Bertie's uncle] 
Maude Stanley [Bertie's aunt]

Lady Stanley [Bertie's maternal grandmother]

Miss Sellers

John Waldegrave [Bertie's Cambridge friend]

Canon and Mrs. Wilberforce

Mr. [Israel] Zangwill [novelist and social critic]

\section{APPENDIX III: LIST OF WEDDING PRESENTS}

The following list is a complete transcription, with minor editing, of Alys's record in "A Locked Diary". The date column also includes the notation "B.", indicating which thank-you letters Bertie was to write. (None of them are known to be extant.) Not printed are the marginal figures in Alys's hand indicating the number of gifts to that point; her last figure, one before the end, is 215 . When it can be ascertained that a book gift is still in Russell's library, that fact is noted in square brackets, with the shelf number. Sometimes the Russell library edition is old enough to be the edition given to the couple, but the absence of Bertie and Alys's bookplate makes it less than certain that it is the gift book. Such items are marked with a query. One book given to them-Michael Field's Long Ago (London: Bell, I889)—is not in Russell's library, but it is in the Russell Archives as the result of an independent purchase some years ago.

\section{May '94 Uncle Horace and Aunt Margaret Smith-£40.0.0}

May '94 Auntie Lill-old silver sugar bowl and cream jug

June '94 Mrs. Alan Cathcart-silver stamp box

June '94 Miss Florence Ayling-wooden chair, poker worked by herself

June '94 Mrs. Alice Gordon Gulick-gold brooch, axe-shaped Toledo ware

Aug. '94 Mrs. Tuckett-morocco bound copy Imitation of Christ

Sept. '94 Miss McCoy-knitted Iceland wool shawl

Oct. '94 Mary and Elisabeth Stuart-green leather work-case [entry in Bertie's hand]

Oct. '94 Mary Costelloe-framed etching of Klinger's

Oct. '94 Uncle James and Aunt Mary-£20.9.0

Oct. '94 Lady Albinia Hobart-Hampden-silver and velvet calendar case

Nov. '94 Miss Alex Horne-Purves-china heart-shaped box

Nov. '94 Lady Stanley of Alderl[e]y-old French neck ornament

B. Lady Russell-silver tea pot and cream jug and sugar bowl

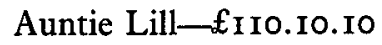

Miss Clara Forge-paper knife

Lloyd and Mayburny Smith-green leather purse

B. Lady de Clifford-carved cocoa nut and silver tobacco jar Miss Kate Ellis-handkerchief case

Miss Bonté Sheldon Amos-book

Miss Shedlock-Daudet's Contes Choisis

Mrs. Spencer-Cowper-silver manicure set

Harold Joachim - old chair

Graham Wallas-porcelain head

B. Miss Elliot-revolving bookcase

Lady Henry Somerset-travelling bag

Lady Darcy-inlaid wood tray

Mr. and Mrs. Wm. Fowler-green silk portfolio and letter

The Servants $\left(\begin{array}{l}\text { Mrs. Martinson } \\ \text { Lucy Martinson } \\ \text { and Jessie Davey }\end{array}\right)$ letter scales

Lady Agatha Russell-china tray and tea set

Miss Belloc-Alf. de Musset's poems

Mrs. Ed. Mounsey-Bulgarian tea cloth

Maggie Vaughan Williams-tea spoon

Adeline, Duchess of Bedford-blue brooch set with pearls

Countess Somers-red leather letter case

B. Honourable Maude Stanley-silver inkstand

B. Claud Russell-paper knife

B. Sir Wm. and Honourable Lady Melville-2 little silver dishes

B. Lady Edmond Fitzmaurice-Cranford [Russell's Library, 609]

B. Mr. Howard Marsh-Jane Austen [Russell's Library, 549-553]

B. Mr. Archibald and Lady Georgiana Peel-2 silver pepper pots

Sir John and Lady Lubbock-book stand

Mr. Zangwill-Trans. of Michel's Rembrandt, 2 large vol. Mr. and Mrs. Sidney Webb-Atlanta in Calydon, Kelmscott Press, vellum bound

Mr. and Mrs. Ed. Martins-silver egg boiler

Mrs. Massingberd-silver tray with old $18225 /$ coin in centre

Miss Leithead-large brass tray 
Dowager Duchess of Abercorn-silk writing set

Mr. and Mrs. Murray Smith-silver pocket knife

B. Capt. and Mrs. W. Fox-Pitt-little silver gilt plate

B. Mr. Geo. Russell-framed engraving of Francis, v Duke of Bedford

Mr. Binney Dibbler-Confessions of an Opium Eater

[? Russell's Library, 582]

Miss Fitzpatrick-2 vol. Rossetti

Mrs. Frederic[k] Harrison-4 vol. of the poets

Anna Maria Fox-book-The Cloud of Witness

B. Mrs. Walrond-book

B. Sir. A. and Lady Boothwick-4 silver salt cellars

B. Miss Villiers-portfolio

Miss Emma Fuller-2 candlesticks

Miss H. Fairchild-book Thoughts on the Marriage Service and 2 calendars

Mrs. Sheldon Amos-white embroidered bag

Sister Lily-3 books

Mr. Little-marmalade dish

Mr. Britten-picture

Miss Maud Adeane-blue parasol with silver top

Miss Charlotte Hamburg-2 morocco cushions

Miss Etta McArthur-glass vase

B. Mr. and Mrs. Rollo Russell-silver butter dishes

B. Mrs. Antrobus-gold travelling clock

B. Lady Russell's servants-silver tea kettle Mrs. Boden-little gold spoon

B. Mr. and Mrs. Villiers-2 blue Indian vases Mr. Phillimore-large book on Albert Moore

B. Maurice Sheldon Amos-io vols. of Peacock's works

[Russell's Library, 7 vols. only, 523-529]

B. Mr. Moore

Mr. Wedgwood $\}$ Shakespeare's Songs-Kelmscott Press

Mr. Dakyns

Miss Graham-Tartine china set

Evelyn Smith-two silver hat pins

Emma Smith-gold safety pin

Alban and Wilson Smith-coffee urn

B. Prof. and Mrs. Fraser-Reminiscences of Yarrow

Mrs. Philpot-Thoughts of Emp. Antoninus and English Lyrics

Misses Cust-Omar Khayyam beautifully bound
Miss Horne-3 vols. Pater

Mrs. Horne-I vol. Pater

Mrs. Anne Fowler-silver pen and pencil

B. Lady Russell-complete set of Waverley novels

[Russell's Library, 485-509]

B. Lady Agatha-Robertson's Sermons [? Russell's Library, 1795-1798], Lowell's Essays and Imitation of Christ Misses Kinsella-gold hat pin

Mrs. Robinson - silver calendar case

B. Miss Mildred Hugh Smith-little tray

Sister Ella and Sister Jeanette-framed picture of Cairo

Logan-framed pictures of Wm. Lord Russell, and

Wriothesley Lord Russell

Miss Bathurst-silver pencil

B. Mr. Cobden-Sanderson-Dream of fohn Ball bound by himself [Russell's Library, 885]

Club Girls-portfolio

Mr. and Mrs. Bright-looking-glass

Nurse Dorothy Tomlinson-Moore's Poems

Mrs. Russell Gurney-tea kettle

B. Mr. Rollo Russell-portfolio

B. Mrs. Rollo Russell-book

Father-chiming clock

Mother-tea basket

Miss Winkworth-travelling clock

Mrs. Isaac Braithwaite-silver sweet dish and tongs

B. Mr. Fred Hamilton-silver cream jug

B. Lady Charlotte Portal—set of leather covers for household books

B. Lady Arthur Russell—seal

Mr. Roger Fry_painting by himself

Miss Bristower and Mrs. Garnett-2 silver candlesticks

Mr. and Mrs. Podmore-carved ivory ball

Miss Stanley-cushion

Miss Susan Lushington-silver sugar tongs

Logan—old box

Juliet Deschamps-bracelet

Miss Bremner-handkerchiefs

Bevan and Martha Braithwaite-Family Bible

B. Mr. Bowan-2 silver pepper pots

B. Mr. Coneybeare-2 carving knife rests

B. Miss Bühler-framed photo. of Watts' Hope 
B. Mr. and Mrs. John Villiers-turning bookcase

B. Mr. Geo. Elliot-3 vols. Sydney Smith

Mr. and Mrs. and the Misses Joachim-turning bookcase Mrs. Wrintingham-brown rug

Mr. Richard Smith-Florentine mosaic card receiver

Lady Mount Temple-r doz. Harlequin spoons

Emily Dawson-silver chatelaine

Mrs. Dawson-silver match box for chatelaine

Helen Dawson-silver knife and pencil for chatelaine

Mich[a]el Field-Long Ago (poems by self) [Russell Archives]

Mr. Evans of Leicester-Norwegian brooch

Mr. and Mrs. Barnford Slack-silver box

Miss Violet Wilberforce-silver pen wiper

Mr. and Mrs. Harry Freeman-white marble box

Mr. and Mrs. Ernest Rhys-Spenser [Russell's Library, 1322] and Sydney [? Russell's Library, I052]

B. Mr. Sanger-Tourgenieff

B. Mr. Tansley-Petrarch [Russell's Library, 518] and Dante [Russell's Library, 519-2i்]

B. Dr. and Mrs. Anderson-Well,Worn Roads by Smith

B. Harold Russell-silver candlestick

B. Lord Russell-travelling bag

B. Mrs. Erskine-Austin Dobson

Aunt Margaret-old gold silk hkf. holder

Mr. and Mrs. Nowers-Poets on Poets

Mr. Will Rothenstein-picture

Mr. and Lady Isabel Margesson-silver pen and pencil

B. Mr. Alfred Peel-glass match box

Y Branches-brass standard lamp, yellow silk shade

Mr. Roland Vaughan Williams-silver plate with Welsh inscription

Miss Eva Smith-tea cloth

Sub Committee B.W.T.A.-silver sugarer

Miss Hunt, Miss Hood and Mrs. Ward Pool-bound copy of Miss Willard's birthday book

Sir Roland and Lady Vaughan Williams-portfolio

Miss V. Williams-pearl handled paper cutter

Mrs. Costelloe-2 silver candlesticks

Mr. and Mrs. Fox-Pitt-6 forks

Miss Clifford-old silver knife and fork

Canon and Mrs. Wilberforce-silver shoe horn and buttonhook
Miss Wallace-Clews to Holy Writ

Mr. and Mrs. John Shaw_-brass vase

Miss Kathleen Fitzpatrick-Bard of the Dimbovitza

Mr. and Mrs. Ed. Warren-2 silver pepper pots

Mr. S. George Lane Fox-penknife

Mrs. Kingston-nut crackers

Mr. and Mrs. Scott-two glass vases in brass stands

Evelyn Nordhoff-portfolio and letter case made by herself Mr. and Mrs. Nordhoff-fan

B. Mr. and Mrs. Warburton-brass twirling bookcase

Mr. and Mrs. Nevile Jodrell-little silver dish

Mr. and Mrs. Bond Thomas-2 vases

Sir Roland Vaughan Williams-tea caddy

Mr. and Mrs. Lyulph Stanley-jam pot with gold lid and spoon

Miss Sellers and Miss Lowndes-brass tea kettle hob

Mr. Stanley Mackower-2 vols. of Herrick

Miss Blanche Featherstonehaugh-metal and leather photo. frame

B. Mr. and Mrs. Childers-standing lamp

B. Lady Burdett-lamp

Mrs. Mary B. Willard-china tea caddy

Mr. and Mrs. Bernard Ellis-silver Norwegian clasp

Dr. Jas. Carey Thomas-silver bread tray

Mr. and Mrs. T. K. Worthington-silver cake dish

Mr. and Mrs. Morris Carey-silver tea caddy

Mr. and Mrs. Harry Thomas-silver bonbon dish

Master Arthur Russell—brass and glass stamp licker

Mrs. and Miss Shearman-2 doyley mats

Miss Lina Lawrence-photograph Botticelli Madonna

Miss M. Carey Thomas-cast of Narcissus and cast of

Miss Florence Alice Dike-Cincinnati brown pottery vase

Ray and Karin-tea kettle holder-"We's free"

Miss Marion Lawrence-photograph Mona Lisa

Miss Maud Burdett-clock

Circular Letter-watch bracelet

Lord and Lady Carlisle-framed Sistine Madonna

Miss Houldsworth-

Mrs. Walter Nordhoff-silver button hook and nail file

Mrs. Sarah Whitall-silver tea strainer

B. Mr. and Mrs. Farrington-Animi Figura by J. A. 
Symonds

Miss Greta Finley-gold sugar spoon

Mr. and Mrs. J. Whitall Nicholson-white satin gold

embroidered mantel scarf

Mrs. Snowdon Rhoads and Mrs. Frank Taylor-

embroidered table centre with two side pieces

Mr. and Mrs. J. W. Thomas-silver bonbon dish

Mr. Will Nicholson-Their Wedding Fourney by Howells

Uncle William Nicholson-£I6.0.0

Miss Grace MacInnes-square rosewood stool, inlaid

Mr. R. Trevelyan-Blake's works

Mrs. Carrie Laurence-embroidered centre and doyleys

Mrs. Annie Foster-embroidered tea cloth

Mr. and Mrs. Dugald Stuart-copper lamp

Miss Anna H. Hoy-Japanese fan

Mr. and Mrs. Willie Scull-silver plate

Miss Edith Kendall-opera glasses and parasol

Mrs. Sarah Beck-topaz brooch

Miss Pattie Mellor-silver luggage label

Miss Gertrude Mellor-lemon fork

Frank Costelloe-old desk

Aunt Alice Whitall-tea cloth

Nan Forster-tea cloth

Cr. and Th. Ll. Davies-Blair's Grave illus. by Blake, ed. of I 808

Miss M. M. Gwinn-bronze medallion of Michel Angelo's

Virgin and Child 